\title{
Membumikan Teologi Transformatif Penyetaraan Sosial Umat
}

\author{
Siti Robikah \\ Institut Agama Islam Negeri Salatiga \\ bikarobikah@gmail.com
}

\begin{abstract}
Abstrak
Artikel ini menjelaskan pembaharuan pemikiran keislaman Moeslim tentang teologi transformatif, serta bertujuan memperkenalkan dan merevitalisasi pemikiran keislaman yang hampir terlupakan. Islam sebagai sebuah pondasi kehidupan umat Muslim seharusnya tidak hanya mengedepankan hablum min Allah dan melupakan hablum min an-nas, keduanya haruslah seimbang. Penelitian ini merupakan library reseacrh, dan karya Moeslim Abdurrahman sebagai data primernya. Menurut Moeslim ibadah secara khusyu' harus diimbangi dengan kepedulian sosial. Hal ini menjadi kegelisahan Moeslim ketika melihat realitas umat Muslim saat ini sedang terjajah oleh arus modernisasi yang menyebabkan berkembangnya kapitalisme barat, sehingga berdampak meningkatnya kemiskinan dan kebodohan di Indonesia. Penelitian ini menghasilkan temuan bahwa dalam teologi transformatif Moeslim menawarkan pembaharuan dalam bidang ekonomi dan pendidikan melalui pemberdayaan masyarakat dengan pengadaan lapangan pekerjaan dan perwujudan pesantren model baru yang melahirkan pemikir muslim berbasis pada pembebasan atas ketertindasan sebagai tujuan utama teologi transformatif.
\end{abstract}

Kata kunci: Kemiskinan, kebodohan, Moeslim Abdurrahman, teologi transformatif 


\begin{abstract}
This article describes the renewal of Moeslim's Islamic thinking about transformative theology, and aims to introduce and revitalize Islamic thought that is almost forgotten. Islam as a foundation for the life of Muslims should not only prioritize the hablum min Allah and forget the hablum min an-nas, both must be balanced. This research is a reseacrh library, and the work of Moeslim Abdurrahman as the primary data. According to Moeslim worship in particular 'must be balanced with social care. This has become Moeslim's anxiety when he sees the reality of Muslims today being colonized by the flow of modernization which has led to the development of western capitalism, thus impacting increasing poverty and ignorance in Indonesia. This study yields findings that in transformative theology Moeslim offers reforms in the field of economics and education through community empowerment with job creation and the realization of a new model of pesantren which gives birth to Muslim thinkers based on liberation of oppression as the main objective of transformative theology.
\end{abstract}

Keywords: Ignorance, moeslim Abdurrahman, transformative theology, poverty

\title{
Pendahuluan
}

Manusia dalam sejarah terbagi menjadi beberapa kelas sosial, sebagian menempati kelas bawah dan sebagian lainnya menempati kelas atas. Manusia terpisahkan oleh perbedaan yang signifikan, diantaranya faktor ekonomi dan pendidikan. Manusia unggul dalam kuantitas, akan tetapi rendah dalam kualitas. Kelompok yang berada di kelas bawah ini dikenal dengan kelompok mustadh'afin atau kelompok tertindas (Kadar, 2005, hal. 29). Kemiskinan dan ketertindasan selalu ada dan menjadi bagian dari problem yang tidak pernah usai dibahas dan mencoba dipecahkan oleh banyak pakar. Tulisan ini akan lebih jauh membahas tentang bagaimana Islam memahami masalah kemiskinan dan ketertindasan. Islam memiliki pandangan khas tentang kemiskinan. Islam sering menyebut kemiskinan dan ketertindasan dengan dua kata kunci, yakni dhu'afa dan mustadh'afin. Terma pertama lebih merujuk pada "orang yang lemah" dalam arti bawaan sejak lahir atau karena musibah dan kecelakaan (QS. atTaubah 91) dan yang terakhir merujuk kepada "orang-orang yang dilemahkan/tertindas" oleh pihak lain yang berkuasa dan kuat (QS. al-Anfal 26).

Azhar Basyir menyebutkan bahwa kaum dhu'afa adalah golongan lemah secara sosial sedangkan mustadh'afin adalah golongan lemah dalam kategori politis. Azhar Basyir memilih pendekatan religius yang dirumuskan secara tepat untuk menyadarkan 
masyarakat. Agama perlu tampil sebagai inspirasi dan ajarannya dapat memotivasi kelompok dhu'afa menuju kehidupan dinamis, kreatif dan produktif. Ini disebabkan pemecahan masalah kemiskinan tidak hanya menyangkut modal kerja, tetapi juga nilai kultural dan spiritual. Karena itu, menurutnya diperlukan upaya penyadaran bahwa mereka mampu mengubah nasib kehidupan mereka (Wahyudi, 1999, hal. 105). Oleh sebab itu, pada wilayah ini peran agama menjadi penting dalam kehidupan sosial untuk menjawab problematika umat, tutama terkait dengan kemiskinan.

Kemiskinan merupakan masalah utama kehidupan banyak umat manusia. Dewasa ini, kemiskinan tidak mungkin dapat diselesaikan hanya dengan institusi kebajikan agama individual. Pemikir-pemikir agama harus berani mengambil terobosan dengan refleksi dan menggugah kepekaan rohani, kepada pihak-pihak yang lebih luas. Sehingga agama tidak menjadi pelarian semu dengan dalih mencari ketenteraman spiritual, yang pada dasarnya merupakan pelestarian kesengsaraan sosial yang nyata, yang hendak ditutup-tutupi (Abdurrahman, 1997, hal. 200).

Umat Islam selama ini cenderung keliru mengartikan ibadah dengan membatasinya pada ibadah-ibadah ritual. Betapa banyak umat Islam yang disibukkan dengan ibadah mahdhah tetapi mengabaikan kemiskinan dan kebodohan yang diderita saudara-saudara mereka. Banyak orang kaya Islam yang menghabiskan harta untuk acara keagamaan, disaat ribuan anak tidak dapat melanjutkan sekolah, ribuan orang tua menanggung beban untuk mencari sesuap nasi dan bahkan orang-orang Islam yang terpaksa menjual iman dan keyakinan kepada tangan-tangan kaum lain yang penuh kasih (Rakhmat, 2004, hal. 57). Realitas tersebut menggabarkan bahwa memahami agama dalam artian ritual saja tidak menjamin pemeluknya sadar akan kondisi sosial, tetapi agama harus dipahami lebih jauh yaitu agama harus hadis dalam wilayah-wilayah sosial dan etika sehingga ajaran agama dapat dirasakan oleh lapisan pemeluknya, seperti merealisasikan zakat, infaq dan sadaqah sebagai tonggak perlawanan atas kezaliman sosial.

Menurut data terakhir Badan Pusat Statistik (BPS) angka kemiskinan mengalami kenaikan dari tahun ke tahun. Pada bulan Maret 2015, jumlah penduduk miskin (penduduk dengan pengeluaran per kapita per bulan di bawah Garis 
Kemiskinan) di Indonesia mencapai 28,59 juta orang (11,22 persen), bertambah 0,86 juta dari 27,73 juta orang (10,96 persen) pada bulan September 2014 (Data diambil dari Badan Pusat statistik diakses pada tanggal 11 Mei 2016). Informasi tersebut menunjukkan bahwa problem kemiskinan belum dapat dituntaskan.

Metode yang digunakan oleh BPS dalam mengukur kemiskinan di Indonesia terdapat 14 macam baik di pedesaan maupun perkotaan. Keempat belas indikator tersebut adalah (1) luas lantai rumah; (2) jenis lantai rumah; (3) jenis dinding rumah; (4) fasilitas tempat buang air besar; (5) sumber air minum; (6) penerangan yang digunakan; (7) bahan bahan bakar yang digunakan; (8) frekuensi makan dalam sehari; (9) kebiasaan membeli daging/ayam/susu; (10) kemampuan membeli pakaian; (11) kemampuan berobat ke puskesmas/poliklinik; (12) lapangan pekerjaan kepala rumah tangga; (13) pendidikan kepala rumah tangga; dan (14) kepemilikan aset. Ditengarai, keempat belas indikator tersebut tidak dapat digunakan untuk mengidentifikasi dimensi kemiskinan yang sedang dialami oleh rumah tangga miskin di Indonesia, apakah berdimensi struktural atau kultural. Realitas di Indonesia menunjukkan, sejak tahun 1980-an dan mungkin hingga kini, kemiskinan yang sebagian besar dialami oleh rumah tangga justru lebih berdimensi struktural, baik di pedesaan maupun perkotaan.

Menurut Selo Soemardjan yang dikutip oleh Alfian (1980, hal. 69) mengaskan bahwa kemiskinan struktural adalah kemiskinan yang diderita oleh suatu golongan masyarakat karena struktur sosial masyarakat itu tidak dapat ikut menggunakan sumber-sumber pendapatan yang sebenarnya tersedia bagi mereka. Sedangkan kemiskinan kultural menurut Chambers dan Nasikun adalah kemiskinan yang mengacu pada persoalan sikap seseorang atau kelompok masyarakat yang disebabkan oleh faktor budaya, seperti tidak mau berusaha memperbaiki tingkat kehidupan, malas, pemboros, tidak kreatif meskipun ada bantuan dari pihak lain (Khomsan \& Dkk, 2015, hal. 3). Akibat dari adanya struktur kemiskinan tersebut berdampak pada adanya kesenjangan sosial di kalangan masyarakat. Pada wilayah ini terdapat kesenjangan dalam memahami realita agama dan budaya, di mana budaya yang bersifat negatif seperti mengharap bantuan dipahami sebagai bagian dari ajaran agama dan agama diyakini mengajarkan tentang memberi. Perilaku tersebut berdampak pada terpuruknya kehidupan beragama. 
Salah satu pemerhati masalah kesenjangan sosial, Moeslim Abdurrahman, memberikan sumbangsih pemikirannya dalam mengatasi masalah-masalah kehidupan yang empiris (empirical problem) seperti kemiskinan yang menjadi sebab adanya kesenjangan sosial di masyarakat. Melalui teologi transformatifnya, Moeslim memberikan fasilitas sebagai kerangka bacaan melihat realitas. Dalam artikel ini penulis memfokuskan pembahasan teologi transformatif Moeslim Abdurrahman dalam upayanya mengentaskan kemiskinan di negara Indonesia.

Kajian tentang teologi transformatif telah dilakukan. Toha Rudin Rizal (2016) membahas tentang gambaran konflik bermatras agama di Indonesia (problem solving berbasis teologi transformatif). Tulisan Toha mencoba mengkaji secara intens seputar persoalan tindak kekerasan di Indonesia yang mengatasnamakan agama (legal doctrine) dan berusaha menguak hakikat akar persoalan yang melatarbelakanginya. Model resolusi berbasis teologi transformatif menjadi sangat signifikan. Tawaran resolusi konflik yang lebih paradigmatik dan holistik berbasis teologi transformatif relevan dengan kondisi konfliktual bernuansa agama di Indonesia. Penelitian ini tidak secara khusus menganalisis pemikiran Moeslim Abdurrahman tentang teologi transformatif sebagai solusi alternatif, kendati tetap menyertakan pemikiran Moeslim secara singkat.

Tasmuji (2011) meneliti tentang teologi transformatif Jaringan Islam Liberal. Temuan dalam artikel ini adalah adanya rekonstruksi teologi yang dilakukan kaum liberal termasuk JIL merupakan upaya mencari sintesis atau titik temu pemahaman antara pemahaman umat Islam yang bersifat tekstualis atau literalis dari sumber ajaran suci Islam dan pemahaman liberal Barat. Akan tetapi JIL terjebak pada posisi yang cenderung pada pihak Barat, sehingga kelompok ini dianggap dan dituduh oleh kelompok Islam fundamentalis, yang cenderung pemahami teks-teks suci secara tekstual-literalis itu, sebagai kaki-tangan Barat dan bahkan sebagai musuh dari dalam Islam sendiri atau sebagai anti-tesisnya. Dengan model pendekatan dalam memaknai teks-teks suci sebagaimana yang dilakukan oleh kelompok Islam Liberal itu, kemungkinan besar akan mendapakan tempat di ruang publik khususnya pada dunia akademik atau perguruan tinggi. Wacana yang dikembangkan pada dunia akademik tersebut akan berdampak pada perubahan wawasan pada masyarakat yang lebih berjangkauan ke depan yang cukup panjang artinya tidak berdimensi waktu yang pendek. Penelitian Tasmuji ini tidak secara spesifik mengkaji pemikiran teologi transformatif Moeslim Abdurrahman dan relevansinya dengan problem kemiskinan di Indonesia sebagaimana yang dilakukan penulis. 
Muthoharoh (2013) juga membahas pemikiran Moeslim Abdurrahman tentang teologi transformatif, namun penelitian ini menganalisis relevansinya terhadap pemikiran keagamaan di era kontemporer. Kendati serupa, namun kajian yang dilakukan Muthoharoh berbeda dengan kajian yang dilakukan penulis, karena penulis spesifik menganalisis relevansi pemikiran teologi transformatif Moeslim dalam upaya mengentas fenomena kemiskinan di Indonesia. Sementara itu, Roni Saputra (2011) mengkaji secara khusus pemikiran Mansour Fakih tentang teologi transformatif. Penelitian ini juga menganalisis relevansi teologi transformatif Mansour Fakih dalam ranah implikasi sosial, implikasi ekonomi tentang alternatif ekonomi berprinsip ketenagakerjaan, implikasi politik tentang legitimasi dan perjuangan politik, dan implikasi sosial tentang mengembalikan teologi dalam perubahan sosial.

\section{Metode}

Artikel ini merupakan artikel yang bersifat kepustakaan (library research), yaitu penelitian yang dilaksanakan dengan menggunakan literatur, baik berupa buku, catatan, maupun hasil penelitian terdahulu. Beberapa jenis penelitian kepustakaan (library research), diantaranya kajian pemikiran tokoh, analisis buku teks, dan kajian sejarah. Penelitian pemikiran tokoh yakni penelitian yang berusaha menggali atau memahami pemikiran tokoh tertentu melalui karya-karya yang ditinggalkannya. Penelitian ini mengkaji pemikiran Moeslim Abdurrahman tentang Teologi Transformatif dalam upayanya mengentaskan kemiskinan di negara Indonesia. Sumber data primer penelitian ini adalah buku karya Moeslim Abdurrahman yang berjudul Islam Transformatif, sedangkan data sekunder berasal sumber kepustakaan lain yang memuat pembahasan teologi transformatif dalam kontek upaya mengentaskan kemiskinan di Indonesia. Data dari beragam sumber kepustakaan, baik primer maupun sekunder, disajikan secara deskriptif dan selanjutnya dianalisis dengan menggunakan pendekatan sosiologi.

\section{Moeslim Abdurrahman dan Teologi Transformatif}

Cendekiawan kelahiran Lamongan, 8 Agustus 1947 ini adalah Doktor antropologi dari University of Illinois, Urbana USA. Moeslim terlahir dari keluarga 
petani Muhammadiyah. Setelah lulus dari sekolah rakyat pada pertengahan tahun 60an, Moeslim menjadi santri di Pesantren Raudhatul 'Ilmiyyah Kertosono Jawa Timur, pesantren yang diasuh Kyai Salim Akhyar yang merupakan murid generasi pertama Kyai Hasyim Asy'ari pendiri Nahdlatul Ulama'. Kemudian Moeslim melanjutkan studinya di fakultas Tarbiyah Institut Agama Islam Muhammadiyah Surakarta.

Pada tahun 2000 Moeslim meraih gelar Ph.D dalam kajian antropologi University of Illinois, Urbana USA dengan disertasi yang berjudul On Hajj Tourism: In Search of Pity and Identity in The New Order Indonesia. Gelar doktornya di bidang antropologi mempengaruhi pendekatan-pendekatannya pada studi keagamaan yang lebih antropologis dan menggunakan teori-teori sosial kritis. Hal ini membentuk watak pemikiran Moeslim lebih transformatif (Fuad, 2015, hal. 138). Beberapa buku Moeslim yang sudah dipublikasikan yaitu Menafsirkan Islam dalam Tradisi dan Persoalan Umat (Surakarta: UMS, 1990), Kang Thowil dan Siti Marginal (Jakarta: Pustaka Firdaus, 1995), Islam Transformatif (Jakarta: Pustaka Firdaus, 1996), Semarak Islam Semarak Demokrasi (Jakarta: Pustaka Firdaus, 1997), Islam sebagai Kritik sosial (Jakarta: Erlangga, 2003), Islam Yang Memihak (Yogyakarta: LkiS, 2005). Tulisan-tulisan Moeslim yang telah dipublikasikan memberikan sebuah wacana keberpihakan terhadap kaum lemah yang diaplikasikan dengan keaktifannya di Lembaga Swadaya Masyarakat (LSM). Pada tahun 2012 beliau dirawat di rumah sakit Dr. Cipto Mangunkusumo karena sakit jantung dan wafat pada usia 64 tahun.

Teologi pembebasan dalam kontek pemikiran Islam kontemporer mencuat ke permukaan sebagai sebuah keniscayaan sejarah. Paradigma ini muncul seiring dengan adanya fenomena sosial berupa kemiskinan, kebodohan dan ketidakadilan masyarakat Islam. Banyak pemikir Islam kontemporer merasa gelisah dengan hal tersebut dan berusaha mencari solusi tepat atas realitas yang dihadapi masyarakat Islam (Ahmad, 2011, hal. 51). Pemikiran Moeslim Abdurahman ini bukanlah kali pertama yang muncul dalam dunia Islam. Pada era sebelumnya Islam telah diperkenalkan dengan pemikiran cendikiawan seperti Hassan Hanafi dengan Al Yasar Al Islami, Asghar Ali Engineer dan Farid Esack dengan Teologi pembebasan. Teologi Transformatif Moeslim pada hakikatnya hampir sama dengan pemikiran-pemikiran tokoh-tokoh tersebut, akan tetapi ada beberapa perbedaan dari diskursus mengenai penindasan dan kemiskinan. 
Menurut Hassan Hanafi, salah satu tugas Al Yasar Al Islami (kiri Islam) adalah membebaskan Palestina dari zionisme (Shimogaki, 2007, hal. 14), Asghar Ali Engineer memunculkan teologi pembebasan di Amerika Latin. Pada masa itu terjadi penindasan serta gerakan represif dari penguasa dan pemerintahan oligarki yang memberikan kehidupan sengsara kepada rakyat. Teologi pembebasan Farid Esack muncul di Afrika karena perjuangannya dalam membebaskan masyarakat dari sistem "apartheid". Di Indonesia, Moeslim memperkenalkan teologi transformatif atas dasar fenomena realitas kehidupan yang timpang.

Moeslim Abdurrahman sebagai salah seorang penggagas utamanya menjelaskan bahwa Islam transformatif merupakan Islam praksis sosial, di mana agama diterjemahkan dalam keberpihakan kepada kaum miskin. Dalam refleksi Moeslim, sebagian besar umat Islam seringkali memperlakukan agama sebagai lembaga yang mengatur tata cara pengabdian kepada Tuhan, sehingga nilai ibadah yang tertinggi dalam kacamata umat adalah dengan melakukan ritualitas secara komprehensif berdasar aturan-aturan baku yang telah ditetapkan. Menurut Moeslim, agama tidak dijadikan sebagai kekuatan pendorong untuk melakukan kebajikan sosial, justru terkesan dijauhkan dari problem sosial (Abdurrahman, 1997).

Moeslim menyatakan bahwa doktrin Islam harus diterjemahkan ke dalam ideide yang tidak sekedar bercorak intelektualistik yang mungkin tidak mampu menumbuhkan atau menggugah kesadaran kolektif masyarakat dalam melakukan perubahan sosial. Hal itu dapat disebabkan oleh ketidakpekaan gagasan-gagasan intelektual terhadap realitas hegemonik, yang berakibat bahwa akan berlawanan dengan utopia emansipasi pada tingkat pentingnya transformasi sosial. Sebab, gagasan Islam yang mencerahkan tidak selamanya memberi pengaruh proses memerdekakan dan membebaskan, kalau hal itu tidak lahir dari proses kritik ideologis-transformatif (Abdurrahman, 2005, hal. 116).

Menurut Moeslim, sangat berbahaya jika reintelektualisasi Islam yang mencerahkan memberi keluasan berfikir namun tanpa kepedulian untuk berpihak secara autentik memperjuangkan pedagogis kemanusiaan. Isu tersebut disinggung Moeslim karena adanya soal pluralisme, multikulturalisme, kebebasan berfikir dan 
perlindungan hak-hak atas perbedaan identitas hanya menjadi perdebatan. Jika isu tersebut tidak diberi referensi dari konstruk sosialnya, maka wacana Islam yang spekulatif tekstual cenderung tidak mempunyai dialektika kepekaan terhadap masalah opresi atau eksploitasi. Dampak lebih fatal adalah keterkaitannya dengan tujuan perubahan sosial yang lebih adil justru akan terlupakan (Abdurrahman, 2005).

Transformasi memang jalan yang paling manusiawi untuk mengubah sejarah kehidupan umat manusia. Sebab dalam proses ini yang berlaku adalah pendampingan, bukan pengarahan apalagi pemaksaan. Transformasi pada dasarnya adalah gerakan kultural yang didasarkan pada liberalisasi, humanisasi dan transendensi yang bersifat profetik, yakni pengubahan sejarah kehidupan masyarakat oleh masyarakat sendiri ke arah yang lebih partisipatif, terbuka dan emansiparotis. Suatu cita-cita yang menjunjung tinggi harkat dan harga kemanusiaan, keyakinan orang dihargai dan perbedaan pendapat menjadi tradisi. Mencapai situasi semacam itu harus disadari memang tidak mudah, namun harus ada yang memulai, yaitu siapa saja yang dalam pandangan hidupnya peduli terhadap ketimpangan sosial sebagai tantangan iman bersama (Abdurrahman, 1997).

Orientasi emansipasi sosial dari teologi transformatif demikian kuat. Menurut Moeslim gagasan ini hendak menemukan ide Tuhan kembali secara partisipatoris dalam pergumulan umat manusia yang sekarang ini mengalami proses dehumanisasi melalui refleksi teologis yang bersumber dari sejarah perjuangan kehidupan sehari-hari. Pandangan teologis Islam mesti diarahkan kepada penumbuhan kesadaran kolektif melalui apa yang disebut counter hegemony (hegemoni tandingan) melawan penindasan dalam relasi struktur kekuasaan. Karena itu, reintelektualisasi tidak dapat dipisahkan dari kerja praksis sosial, sehingga hubungan antara berpikir dan ortopraksis menjadi satu kesatuan, sama halnya dengan teks dan sejarah yang mengitarinya (Abdurrahman, 2005). Teologi transformatif dimaksudkan untuk mengetahui bagaimana umat memahami proses sosial yang terjadi di kalangan masyarakat melalui penemuan ide Tuhan yang masih tersimpan dalam kalam-Nya. Melalui pemahaman firman Allah akan ditemukan sebuah terobosan untuk membebaskan umat dari belenggu ketertindasan dalam kemiskinan dan kebodohan. 
Persoalannya adalah bagaimana strategi melakukan tranformasi nilai-nilai Islam pada kondisi masyarakat industrial atau masyarakat informasi saat ini. Menurut Kuntowijoyo, pada dasarnya seluruh kandungan nilai Islam bersifat normatif. Ada dua cara bagaimana nilai normatif tersebut menjadi operasional dalam kehidupan seharihari. Pertama, nilai normatif tersebut diaktualkan langsung menjadi perilaku. Contohnya adalah seruan moral praktis al-Quran, misalnya menghormati orang tua (Kuntowijoyo, 2008, hal. 279). Seruan ini langsung dapat diaplikasikan dalam perilaku kehidupan sehari-hari. Kedua, mentransformasikan nilai-nilai normatif menjadi teori ilmu sebelum diaktualisasikan ke dalam perilaku. Cara yang kedua ini lebih relevan pada saat ini jika ingin melakukan restorasi terhadap masyarakat Islam dalam kontek masyarakat industrial, suatu restorasi yang membutuhkan pendekatan yang lebih menyeluruh daripada sekedar pendekatan legal.

Metode untuk transformasi nilai melalui teori ilmu untuk diaktualisasikan dalam praksis membutuhkan beberapa fase formulasi. Dimulai dari teologi berubah menjadi filsafat sosial kemudian menjadi teori sosial dan terakhir adalah perubahan sosial. Sampai saat ini memang hal tersebut belum dapat dilakukan. Dengan menyadari kekurangan tersebut, kita memang sudah didesak untuk segera merumuskan metode transformai Islam pada level empiris (Kuntowijoyo, 2008). Oleh karena itu, revitalisasi teologi transformatif Moeslim Abdurrahman menjadi penting demi mewujudkan perubahan sosial yang merata di kalangan masyarakat Indonesia.

\section{Trend Baru Teologi Transformatif}

Pemikiran teologi transformatif lahir sebagai respon terhadap dampak negatif dari pembangunan kapitalisme dunia. Dalam sudut pandang teologi transformatif tidak jarang sebuah pembangunan menimbulkan dampak seperti terjadinya alienasi dan dehumanisasi (Ismail, 1993, hal. 38). Gejala alienasi ditandai dengan keterasingan hubungan antara manusia dengan Tuhan ataupun manusia dengan manusia. Adapun dehumanisasi lebih berdampak pada perilaku, pola pikir dan paradigma seseorang dalam menyikapi kehidupan. Kedua hal tersebut mempunyai ciri sama yaitu hilangnya sifat kemanusiaan yang menimbulkan sifat sombong. 
Corak pemikiran teologi transformatif di Indonesia diprakarsai oleh Moeslim Abdurrahman. Term teologi transformatif dimaksudkan Moeslim sebagai pencarian sebuah metode berpikir dan tindakan yang memihak, serta dapat membekali dan mempersenjatai masyarakat untuk bisa bangkit mengentaskan diri dan keluar dari keterbelakangan, kebodohan dan kemiskinan dengan mengesampingkan paradigma modernisasi (Moh. Shofan, 2006, hal. 316). Gerakan teologi transformatif dalam kontek ke-Indonesia-an adalah antitesa dari gerakan Islam peradaban yang dicetuskan Nurcholis Madjid. Teologi transformatif bisa dikatakan sebagai teologi kontektual, yakni sebuah teologi yang dipahami dan didialogkan secara dialektis sesuai dengan kontek problematika kehidupan umat dalam bidang ekonomi, politik, sosial dan budaya (Toha Rudin Rizal, 2016, hal. 57-58). Teologi transformatif merupakan perkembangan teologi yang lebih bersifat praksis, kaum beriman dalam melakukan sebuah tindakan tidak semata bersifat ukhrawi, tetapi juga bagaimana kaum beriman dengan teologinya membangun kedamaian, keadilan, egalitarianisme di dunia ini. Teologi transformatif meniscayakan umat Islam untuk menghindari pemahaman terhadap ajaran agama secara parsial (Toha Rudin Rizal, 2016, hal. 57-58).

Gagasan teologi transformatif berawal dari keresahan Moeslim ketika melihat proses modernisasi atau yang disebut orde baru sebagai "pembangunan", ternyata hanya bisa diakses oleh kelas menengah ke atas saja. Sementara itu, marginalisasi sosial meluas khususnya di kalangan petani dan buruh, yang benar-benar tidak terjangkau oleh pesan Islam yang memihak hegemoni pembangunan tersebut. Dari hal tersebut, Moeslim menyimpulkan bahwa ada suatu keadaan di mana pesan-pesan agama sangat segmentatif dengan proses sosial yang mengusir banyak orang dari modernisasi, dari pembangunan (Abdurrahman, 2003, hal. 182).

Paradigma "modernisasi Islam" cenderung melakukan liberalisasi pandangan yang adaptif terhadap kemajuan zaman tanpa harus meninggalkan sikap kritis terhadap unsur negatif dari proses modernisasi. Persoalannya adalah bagaimana dengan tradisi teks mengembangkan pesan Islam dalam kontek perubahan sosial. Oleh karena itu, modernisasi Islam ini cenderung terlebih dahulu merumuskan ukuran normatif di berbagai bidang kehidupan termasuk ilmu, teori-teori ilmu sosial, sistem ekonomi bahkan busana, sehingga ditemukan corak yang lebih "khas Islam". Paradigma 
modernisasi dalam pemikiran Islam tampaknya lebih memperlihatkan kelenturan, keterbukaan dalam menghadapi dunia yang plural dan terus terbuka (Abdurrahman, 1997). Dalam hal ini para pemikir modernisasi Islam tidak memaksakan kehendak untuk mengislamkan setiap aspek kehidupan dikarenakan otoritas agama sebagai addin dan perkembangan aspek sosial umat Islam mempunyai basisnya masing-masing.

Modernisasi pada dasarnya adalah peradaban Barat yang macet, karena perangkat materialistik tidak memberikan masa depan agama. Oleh karena itu Islam harus mencari alternatif terhadap sekularisme dan ideologi Barat yang tidak manusiawi, yaitu dengan menggali dan membangun norma-norma Islam dalam segala aspek kehidupan. Dalam situasi perkembangan umat Islam yang diwarnai paradigma tersebut, akhir-akhir ini tampak muncul kecenderungan baru melalui isu pengembangan "teologi transformatif". Jika modernisasi lebih bertolak dari isu tentang kebodohan, keterbelakangan dan kepicikan, maka teologi transformatif lebih menaruh perhatian terhadap persoalan keadilan dan ketimpangan sosial. Itulah yang dijadikan sebagai agenda besar yang menjadikan banyak umat manusia tidak mampu mengekspresikan harkat dan martabat kemanusiaannya (Abdurrahman, 1997).

Bagi kalangan cendekiawan, teologi transformatif adalah semua persoalan peradaban manusia sekarang ini dianggap berpangkal pada persoalan ketimpangan sosial-ekonomi, karena adanya struktur yang tidak adil. Struktur yang timpang, bagi kalangan cendekiawan teologi transformatif, dipandang sebagai bagian dosa Barat yang membawa ide modernisasi. Sebab dalam prakteknya, modernisasi sering melakukan eksploitasi terhadap sumber-sumber ekonomi dan informasi, yang hanya bisa dikuasai oleh kelompok-kelompok dan masyarakat kelas elite, sehingga dapat mengontrol sejumlah orang tanpa kesempatan dan harapan untuk mengubah masa depan.

Kalangan cendekiawan teologi transformatif menyimpulkan bahwa agama dalam proses modernisasi melahirkan tiga corak (Abdurrahman, 1997). Pertama, tampil sebagai alat rasionalisasi atas modernisasi atau modernisme, dengan melahirkan perkembangan teologi rasional yang mengacu pada tumbuhnya kepentingan intelektualisme sekelompok akademisi. Kedua, sebagai alat legitimasi atas nama melancarkan dan mendukung berhasilnya program-program modernisasi. Ketiga, 
kelompok masyarakat tertentu terutama "kaum dhuafa", yang tidak terserap dalam dialog besar proses modernisasi dewasa ini, terpaksa menghanyutkan diri dalam impian teologi eskatologis yang bersifat eskapistis. Ketiga karakteristik tersebut menggambarkan tentang perebutan identitas kelas dari masing-masing kelompok dalam melibatkan agama sebagai justifikasi tindakan, seperti peran logika dalam merasionalisasi permasalah agama untuk kepentingan dunia akademisi. Gagasan ini diwakili oleh kelompok pertama. Adapun kelompok kedua, menggunakan agama dalam wilayah dan kepentingan modernisasi, karena agama tidak bisa hidup tanpa tempat dan masa. Begitu juga dengan kelompok ketiga yang menaruh agama dalam kontek spiritual, karena ketidakmampuan melawan arus modernisasi sehingga mereka melakukan pencarian batin untuk melepaskan diri dari modernisasi.

Jadi agama dalam tiga corak diatas tidak berangkat atau menyentuh problem yang ada dalam realitas. Agama berhenti dan hanya asyik mempersoalkan kerangka utopis pada tingkat super-struktur. Dalam situasi semacam itu, teologi harus dirumuskan kembali berdasarkan realitas struktural yang benar-benar hidup dalam kenyataan sehari-hari dan dihadapi oleh kelompok masyarakat Indonesia (Abdurrahman, 1997). Maka dari itu diharapkan agama harus lebih peka terhadap masalah-masalah sosial. Adpaun problem modern ialah ketika agama tidak berani membicarakan kenyataan sejarah di mana orang tidak dapat memilih satu diantara dua kenyataan yaitu akan hadir di lingkungan sosial yang bagaimana dan rahim siapa. Itulah awal ketimpangan sejarah bagi setiap orang. Dalam keadaan demikian, ada dua hal penting yang perlu diperhatikan oleh agama, yaitu:

Agama harus berani melakukan otokritik terhadap pesan dan juga mendefinisikan konsep-konsepnya selama ini. Misalnya tentang konsep tauhid dalam Islam yang berkembang hanya dipahami sebagai sesuatu yang final. Hal yang penting disini adalah bagaimana seseorang bertauhid dalam fragmentasi sosial, sehingga tauhid tidak diartikan hanya tentang Tuhan, tetapi relasi manusia dengan Tuhan dan relasi manusia antar sesama. Pada kontek ini, kita akan menemukan teologi transformatif. Agama harus berani mengajukan satu narasi besar yang baru. Dengan kepedulian pada masyarakat (seperti mengeluarkan sedekah dan sebagainya dalam konsep lama) ini, agama diharapkan lebih mempunyai komitmen untuk menyuarakan ideologi yang 
memperjuangkan keadilan sosial melalui mekanisme redistribusi sosial. Yang semala ini terjadi, agama-agama harus diakui sangat lemah pemihakannya ketika berbicara mengenai sistem sosial yang lebih adil (Abdurrahman, 2003). Dua hal tersebut mengajarkan kita untuk melihat agama sebagai suatu kenyataan dalam kehidupan masyarat. Dengan bahasa sederhana, ajaran agama harus diaplikasikan sesuai dengan kehidupan masyarakat modern, tanpa harus menghilangkan sakralitas.

Agama dalam hal ini diharapkan tidak hanya terfokus pada kesalehan ritual saja akan tetapi lebih pada peranannya dalam merubah realitas yang timpang. Dan inilah yang menjadi fokus teologi transformatif Moeslim Abdurrahman. Gagasan ini mengingatkan satu ungkapan yang ditulis Cak Nur sebagai kritik atas kekerdilan pemeluk agama dalam menghadapi realitas sosia "para sufi yang lari dari kenyataan hidup dan menghindari dunia dengan cara uzlah adalah bentuk ketidakpercayaan pada kekuasaan Tuhan" (Madjid, 2000). Pandangan ini bukan hanya hisapan jempol, karena realitas modern harus dihadapi oleh kaum agamawan dan memberi solusi atas problem yang berkembang untuk menunjukkan eksistensi agama dalam kehidupan sosial.

\section{Teologi Transformatif dan Kemiskinan di Indonesia}

Dalam masa sekarang, ketika dimana-mana umat manusia dan ideologi sedang dilanda krisis, Islam telah memberikan andilnya yang nyata dalam menyelesaikan kemelut kemanusiaan, seperti kebodohan dan kemiskinan. Kita tidak dapat menyelesaikannya hanya dengan motivasi ajaran "kebaikan" seperti sedekah atau zakat, tetapi jelas membutuhkan pemikiran baru yang lebih konsepsional (Abdurrahman, 1997). Dengan bahasa lain, sedekah dan zakat harus dimaknai sebagai realitas yang hadir bagi kehidupan sosial. Perilaku tersebut harus memberi jawaban atas problem kemiskinan yang melanda pemeluk agama. Dengan demikian, kita bisa mengatakan bahwa agama adalah sumber kehidupan dan solusi bagi kehidupan masyarakat umum.

Para ilmuwan sosial membagi dua jenis penyebab kemiskinan yaitu, pertama, kemiskinan karena faktor perilaku individu, yakni sikap individu yang tidak produktif. Kedua, kemiskinan karena struktur sosial, keadaan masyarakat dan tatanannya yang tidak benar (Serraden, 2006, hal.47). Faktor sikap individu dikelompokkan lagi menjadi sebab faktor teologis, yakni pemahaman keliru terhadap istilah zuhud, qana'ah, tawakal 
dan sukur, yang dipahami sebagai sikap keagamaan yang menjadikan seseorang bersikap tidak produktif, dan sebab faktor etos kerja yang rendah,yang disebabkan kebiasaan hidup santai, suka menikmati tanpa mau bekerja keras dan lain-lain.

Upaya untuk memberdayakan kaum miskin dapat menggunakan pendekatan perberdayaan kaum miskin melalui pengembangan sikap individu dan pemberdayaan melalui struktur. Pemberdayaan kaum miskin melalui pengembangan sikap individu dilakukan dengan beberapa langkah, pertama, peningkatan etos kerja dengan cara manajemen waktu, bekerja sesuai bidang dan kompetensinya, pekerjaan yang dilakukan tidak boleh menjadikan lupa karena Allah, serta etos kerja yang tinggi tidak boleh melupakan shalat dan zakat. Kedua, meluruskan pemahaman tehadap konsep zuhud, qana'ah dan sukur. Pemberdayaan kaum miskin melalui pemberdayaan struktur, yakni bisa dimulai dengan mengembangkan sistem perekonomian yang berbasis syariah atau ekonomi yang bersifat Islami, di samping mengoptimalkan ibadah yang bersifat sosial, seperti zakat, infak dan sedekah. Dalam mengatasi kemiskinan, yang pertama harus dilakukan adalah merubah kekeliruan berfikir. Banyak dari masyarakat yang berpendapat bahwa kemiskinan adalah sebuah periode dalam perjalanan kehidupan manusia. Maka dari itu tidak perlu dipersoalkan sungguh-sungguh. Bukankah orangorang yang sekarang ini menuang kesuksesan dahulunya juga mengalami kehidupan yang amat pedih sama seperti apa yang dirasakan oleh orang miskin? Pertanyaan ini merupakan mitos kemiskinan yang overgeneralisasi. Para pakar logika biasanya menyebutnya dengan fallacy of dramatic instance (Rakhmat, 1994, hal. 240). Kekeliruan berfikir semacam inilah yang menina bobokan masyarakat dari kemajuan peradaban.

Menurut Ibnu Hazm, kemiskinan dapat diatasi dengan kesediaan orang kaya memberikan hak orang miskin yang diamanatkan Allah kepadanya. "Berimanlah kamu kepada Allah dan Rasul-Nya dan nafkahkanlah sebagian dari hartamu yang Allah telah menjadikan kamu menguasainya. Maka orang-orang yang beriman di antara kamu dan menafkahkan (sebagian) dari hartanya memperoleh pahala yang besar." Bahwa kemiskinan adalah tanggung jawab bersama bukan menjadi tanggung jawab orangorang miskin tersendiri. Dalam hal ini telah dijelaskan berulang kali di dalam Al Quran dan As Sunnah, sebagian diantaranya menolong dan membela yang lemah, mustadh'afin, adalah tanda-tanda orang yang bertakwa (QS. al-Baqarah 197, QS. al- 
Imran 134, QS. al-Anfal 76, QS. at-Taubah 70, 24, 51, 19). Mengabaikan nasib mustadh'afin, acuh tak acuh terhadap mereka, enggan memberikan pertolongan, akan menjadikan ia pendusta agama (QS. al-Ma'un 1-7).

Membela nasib mustadh'afin merupakan amal utama yang mendapat pahala yang lebih besar dibandingkan ibadah-ibadah sunah. "Barang siapa diwaktu pagi berniat untuk membela orang teraniaya dan memenuhi kebutuhan seorang muslim, baginya ganjaran seperti ganjaran haji mabrur. Hamba yang paling dicintai Allah adalah yang paling bermanfaat bagi manusia. Seutama-utamanya amal adalah memasukkkan rasa bahagia pada hati orang beriman - melepaskan lapar, membebaskan kesulitan atau membayar hutang." (Sabiq, 1982, hal. 12).

Dari nash-nash diatas memperlihatkan bahwa Islam sebagai pembebas dari ketertindasan manusia. Menurut banyak penulis sejarah Islam bukan saja dianggap sebagai agama baru melainkan juga liberating force-suatu kekuatan pembebas manusia. Dari segi inilah Islam sangat cepat sekali tersebar di Indonesia. Pada waktu itu, Indonesia ditindas oleh sekelompok kaum Raja yang feodal. Rakyat harus membayar upeti bahkan harus membanting tulang bagi mereka. Islam datang dengan ajaran persamaan dan pembebasan. Kemudian orang-orangpun berpaling kepada agama baru ini. Pada wilayah berbeda al-Quran sering memberikan perhatian kepada kita untuk senantiasa menjaga keluarga dari generasi memperihatinkan, karena Allah tidak menghendaki hambanya dalam keadaan miskin dan bodoh, sebagaimana tertera dalam QS. an-Nisa' yang menegaskan hendaknya kita menjaga generasi dari lemah dari aspek material dan keilmuan. Kemiskinan di era kontemporer ini bukan hanya dibatasi pada orang-orang yang menerima zakat. Perspektif-perspektif baru tentang kemiskinan menentang perhatian yang sekedar tertuju kepada pendapatan konsumsi sebagai mendefinisikan kondisi masyarakat miskin. Kemiskinan adalah seperangkat deprivasi yang demikian kompleks (Baidhawy, 2015, hal. 65).

\section{Kemiskinan karitas}

Kemiskinan karitas bukan semata menunjukkan adanya kelangkaan dalam hal pemenuhan kebutuhan-kebutuhan dasar (basic needs). Kebutuhan fisiologis dan kebutuhan dasar sangat penting untuk membuat manusia tetap bertahan hidup 
(survival). Kebutuhan-kebutuhan yang sifatnya sangat mendasar ini mencakup sandang, pangan, papan. Miskin karitas ini dapat diperluas hingga mencakup pendapatan, aset fisik (physical capital) dan aset lingkungan seperti pepohonan.

\section{Kemiskinan Kapasitas}

Kemiskinan kapasitas adalah gambaran tentang ketidakpastian, ketiadaan harapan dan masa depan yang berkaitan dengan human capital meliputi pendidikan, life skill, training, kekuatan bekerja, dan social kapital mencakup jenjang sosial seperti kekerabatan, kebertetanggaan dan asosiasi atau organisasi. Upaya yang dapat dilakukan untuk menanggulangi kemiskinan kapasitas adalah dengan membangun kapasitas manusia dan memperluas kesempatan bagi mereka. Model -model pembanguan sumber daya manusia bersandar pada strategi-strategi utama untuk mengeliminasi kemiskinan khususnya pendidikan dasar untuk semua, peningkatan keterampilan hidup, pelatihan kerja, kredit bagi kaum miskin, pertumbuhan yang adil, dan pemberdayaan kaum perempuan. Penciptaan lapangan kerja, meningkatkan pendapatan dan pengentasan kemiskinan dapat dilakukan dengan adanya keuangan mikro. Keuangan mikro adalah alat yang penting dalam strategi pembangunan negara yang diarahkan untuk mendukung pencapaian sasaran pembangunan milenium.

\section{Kemiskinan Otoritas}

Kemiskinan otoritas adalah sebentuk ketidakberdayaan akibat marjinalisasi sosial, marjinalisasi partisipasi, marjinalisasi hak-hak asasi dan marjinalisasi perlindungan hukum. Marjinalisasi sosial adalah suatu pendekatan yang mirip dengan eklusi sosial, yang menjelaskan proses marjinalisasi dan deprivasi kaum miskin yang hidup di pinggiran-pinggiran kota. Marjinalisasi ini merupakan suatu proses melalui mana individu-individu atau kelompok-kelompok dipinggirkan, dikucilkan dari pertisipasi penuh dalam berbagai aktivitas masyarakat dimana mereka hidup. Kondisi semacam ini mencerminkan sebentuk deprivasi sebagai suatu bentuk kemiskinan yang juga hidup di tengah-tengah masyarakat kontemporer dan jauh lebih rumit menguranginya. 
Marjinalisasi Partisipasi, yakni kemiskinan yang disebabkan oleh marjinalisasi partisipasi (termasuk miskin jejaring di tingkat keluarga, tetangga dan asosiasi). Kaum miskin biasanya merana karena mereka tidak memiliki akses untuk berpartisipasi dalam pembuatan-pembuatan keputusan-keputusan dan kebijakan-kebijakan yang penting bagi mereka sendiri. Marjinalisasi hak-hak asasi manusia, yakni peminggiran atau perampasan hak-hak atas hidup, berfikir, reproduksi sehat, pemenuhan kebutuhan dasar dan perlindungan kepemilikan.

Menurut Abdurrahman Wahid yang dikutip oleh Naim (2016) dalam menanggulangi kemiskinan perlu adanya upaya untuk mengaitkan penanggulangan kemiskinan dengan mendudukkan martabat manusia pada tempatnya sebagai makhluk sosial dengan hak-hak asasi dan kebutuhan dasarnya sendiri, pemberian legitimasi keagamaan hanya dalam kerangka kemasyarakatan yang mampu mendorong pengembangan martabat manusia, dan kesediaan melakukan perubahan mendasar dalam pemikiran keagamaan untuk menampung kebutuhan meningkatkan martabat manusia dan kerangka kemasyarakatan yang diperlukan. Sehingga umat Islam melihat persoalan kemiskinan tidak hanya sebagai masalah mikro akan tetapi juga persoalan skala besar yang harus diatasi melalui visi kemasyarakatan bukan hanya dengan pelayanan sosial yang karitatif.

Moeslim menyatakan bahwa apa yang dikemukakan oleh Abdurrahman Wahid yang bercorak liberal ideologis agaklah sulit untuk dilukiskan secara lebih rinci. Akan tetapi hal tersebut dapat dipahami jika mengidentifikasi pemahaman sebagai kelompok Islam totalitas. Aktivitas kelompok tersebut cenderung melakukan counter vailing terhadap situasi kontemporer umat Islam yang dilanda hegemoni Barat, dengan menyatakan bahwa Barat telah dilanda krisis dan Islam harus menjadi alternatif (Abdurrahman, 1997). Salah satu alternatif yang dapat digunakan untuk dijadikan wacana pengentasan kemiskinan yaitu dengan pemahaman kembali Islam transformatif. Hal ini tidaklah hanya dijadikan sebuah wacana akan tetapi dijadikan sebagai landasan sebuah gerakan yang mampu mengubah kehidupan kemanusiaan menjadi lebih adil dan bermartabat. 
Pengembangan teologi transformatif adalah salah satu upaya yang dapat mengatasi perdebatan tentang pilihan antara pendekatan budaya atau struktural dalam mengembangkan masyarakat. Sebab, dalam eksperimentasi teologi transformatif, pada dasarnya umat yang hidup bersama simbol keyakinannya diberi peluang untuk terus menggali kekuatan dari simbol keagamaannya. Itu dalam mengatasi ketimpangan struktural yang mengkungkungnya. Oleh karenya, dalam proses teologi transformatif juga harus melibatkan kegiatan analisis sosial bersama untuk memahami kontek. Selain itu juga diperlukan adanya refleksi iman bersama yang terungkap dalam simbol keagamaannya. Disinilah sebenarnya diperlukan kerjasama antara para teolog, analisis ilmu sosial dan para tokoh untuk memberi fasilitas kepada proses transformasi sosial (Abdurrahman, 1997).

\section{Teologi Transformatif dan Pendidikan}

Muhammad Javad as-sahlani berargurmen tentang hubungan Islam dan pendidikan dalam At Tarbiyah wa At ta'lim fi al-Quran al-Karim, mendefinisikan pendidikan Islam sebagai proses pendekatan manusia kepada tingkat kesempurnaan, dan mengembangkan kemampuannya. Bentuk-bentuk dakwah Islam dalam pendidikan dapat ditarik dari dua ayat yang berkenaan dengan tugas Nabi SAW:

Artinya; (yaitu) orang-orang yang mengikut rasul, Nabi yang Ummi yang (namanya) mereka dapati tertulis di dalam Taurat dan Injil yang ada di sisi mereka, yang menyuruh mereka mengerjakan yang ma'ruf dan melarang mereka dari mengerjakan yang mungkar dan menghalalkan bagi mereka segala yang baik dan mengharamkan bagi mereka segala yang buruk dan membuang dari mereka beban-beban dan belenggu-belenggu yang ada pada mereka. Maka orang-orang yang beriman kepadanya. Memuliakannya menolongnya dan mengikuti cahaya yang terang yang diturunkan kepadanya (Al Quran), mereka Itulah orang-orang yang beruntung (QS. al-A'raf 157).

Artinya; sungguh Allah telah memberi karunia kepada orang-orang yang beriman ketika Allah mengutus diantara mereka seorang Rasul dari golongan mereka sendiri, yang membacakan kepada mereka ayat-ayat Allah, membersihkan (jiwa) mereka, dan mengajarkan kepada mereka Al kitab dan Al hikmah. dan Sesungguhnya sebelum (kedatangan Nabi) itu, mereka adalah benar-benar dalam kesesatan yang nyata (QS. al-Imron 164). 
Ayat pertama dapat ditarik kesimpulan bahwa ada tiga bentuk dakwah yaitu amar ma'ruf nahi munkar, menjelaskan tentang yang halal dan yang haram (syariat Islam), meringankan beban penderitaan, dan melepaskan umat dari belenggu-belenggu. Adapun ayat kedua ada tiga bentuk dakwah yaitu tilawah (membacakan ayat-ayat), tazkiyah (menyucikan diri mereka) dan ta'lim (mengajarkan al-kitab). Pada dasarnya kedua ayat tersebut mengajarkan pemeluknya untuk seantiasa berperilaku adil, baik dan positif pada diri sendiri dan sosial. Dalam bukunya Jalaluddin Rakhmat menjelaskan bahwa dakwah amar ma'ruf nahi munkar dapat dimasukkan dalam tazkiah dan menjelaskan halal haram termasuk pada ta'lim. Dengan demikian dakwah dalam Islam terbagi menjadi empat yaitu tilawah, tazkiah, ta'lim dan ishlah (yang dipakai untuk melepaskan beban dan belenggu-belenggu) (Rakhmat, 1994).

Dalam masalah pendidikan, Moeslim mempunyai gagasan mengenai pusat kajian Islam dengan fungsi dan corak kegiatan yaitu

Pertama, suatu pesantren model baru yang dirancang sebagai pusat refleksi para pemikir Islam, di mana pada waktu tertentu mereka pemikir Islam dapat berdialog dan berefleksi bersama. Jadi semacam Monastry for Islamic Reflection, yang dapat memanifestasikan perlunya ijtihad kolektif. Tradisi pesantren menjadi pilihan karena sebagai tempat refleksi dibutuhkan suasana tidak terlalu formal, dan hubungan satu sama lain lebih dekat, emosional dalam arti menumbuhkan solidaritas intelektual Islam.

Kedua, pesantren juga merupakan simpul jaringan kerja antara para pemikir Islam baik teologi maupun ilmuwan sosial dan para mubaligh serta para pemimpin organisasi Islam. Tujuannya untuk mencari model kerjasama yang terkait dan saling memfasilitasi dalam ragka tumbuhnya proses transformasi umat. Sehingga dengan demikian gerakan pemikir dan gerakan amal saling memfasilitasi.

Ketiga, pesantren sebagai kajian Islam juga diharapkan dapat menjadi dekumentasi dan informasi Islam yang dikelola secara profesional. Semacam clearing house untuuk dokumentasi dan publikasi.

Keempat, melalui program latihan dapat dirancang kaderisasi kepemimpinan umat yang betul-betul dipersiapkan sebagai pemimpin masa depan yaitu, yang memiliki tradisi intelektual yang kukuh, visi sosial yang jelas, dan kemampuan analitis untuk 
membaca umatnya secara tajam. Kelima, Melalui pesantren ini juga diharapkan dapat dikebangkan model baru andragogi Islam. Dengannya dapat membuat umat merasa dekat dengan hidayah Tuhan, menempatkannya sebagai sumber dan pengalaman dekat dan bukannya jauh akibat profesionalisasi wahyu yang elitis (Abdurrahman, 1997).

Dari beberapa uraian bentuk pendidikan yang telah dijelaskan, dapat dijadikan sarana membenarkan pemikiran masyarakat yang masih keliru. Seperti pengelompokan dakwah (pendidikan) Islam oleh Jalaluddin Rakhmat memberikan sebuah pembelajaran mengenai pentingnya keberpihakan terhadap yang lemah (Rakhmat, 1994). Adapun Ishlah (melepaskan beban dan belenggu-belenggu) mempunyai tujuan agar pelajar memiliki kepekaan terhadap orang lain, merasa terpanggil untuk membantu kelompok yang lemah dan sanggup menganalisis kepincangan-kepincangan sosial disekitarnya. Dia mengusulkan contoh-contoh kegiatan yang dapat diaplikasikan dalam keberpihakan terhadap kaum lemah seperti kampanye amal saleh, kunjungan ke kelompok dhu'afa dll. Begitu juga pola yang diusulkan oleh Moeslim berupa melatih kader pemimpin yang memiliki tradisi intelektual yang kukuh dan visi sosial yang kuat merupakan salah satu sarana keberpihakan terhadap kaum yang lemah. Dalam hal ini diharapkan orang-orang yang berpendidikan dapat memulai kepeduliannya terhadap persoalan ketimpangan sosial.

\section{Teologi Transformatif dan Penyetaraan sosial}

Kemiskinan dan kebodohan adalah salah satu keadaan yang menjadi penyebab adanya ketimpangan sosial. Jarak antara orang miskin dan orang kaya, orang pintar dan orang bodoh sangatlah sulit jika didekatkan. Transformatif mengharapkan lahirnya sebuah jamaah (kumpulan dari banyak umat) dengan solidaritas baru yang didasarkan pada kesamaan berusaha, keadilan memperoleh hasil dan keterbukaan dalam kepemimpinan. Tipe jamaah semacam ini akan sangat ideal jika lahir di berbagai tempat sebagai modal organisasi umat yang mengacu terwujudnya masyarakat yang demokratis, beriman dan betakwa kepada Allah, tetapi melahirkan jamaah yang kuat dan tangguh dibutuhkan perencanaan, pendampingan dan komitmen yang jelas dan didasar pada kesamaan visi dan cita-cita bersama yang kuat (Abdurrahman, 1997).

Sejalan dengan pemikiran tersebut, perlu adanya prakarsa mendirikan simpul gerakan umat yang baru, yaitu umat Islam yang mempunyai tujuan hidup yang jelas 
dan maju. Organisasi yang bergerak memfasilitasi gerakan transformasi sosial melalui upaya menghimpun dana dari umat (from people for people). Suatu pusat penggalang solidaritas baru yang menyatukan kepedulian iman dan tanggung jawab sosial antara mereka yang mustadh'afin dan kelompok sosial yang beruntung. Simpul gerakan umat ini bisa saja menghimpun dana yang dapat dijadikan stimulan dalam proses transformasi yang tentu saja sangat dibutuhkan dalam pendampingan sosial (Abdurrahman, 1997).

Pendampingan sosial semacam itu memang tidak mudah. Banyak masyarakat yang ingin melakukan pendampingan sosial dengan cara meminjamkan modal kepada mustadh'afin. Tetapi perasaan takut atas kerugiaan akibat kegagalan dari pinjaman modal tersebut menjadikan rasa ikhlas menjadi berkurang dan akibat kegagalan tersebut semangat untuk merubah kehidupan akan surut. Hal-hal seperti inilah yang menjadi tantangan bagi semua yang bergerak dibidang transformasi sosial, yaitu bagaimana menggulirkan proses transformasi dengan kekuatan umat sendiri, yang bertumpu pada bangunan solidaritas baru yang tidak dalam skema patron klein, tetapi karena didasari pada keyakinan iman yang mendalam. Maka dari sinilah akan terwujud kehidupan setara di masyarakat. Upaya pengentasan kemiskinan dan kebodohan melalui langkah pendampingan sosial merupakan salah satu pengamalan dari teologi transformatif. Pada dasarnya, teologi ini bergerak pada pendampingan bukan pemaksaan. Mendampingi kaum mustadh'afin untuk mampu merubah kehidupannya melalui kemampuan dan usaha yang mereka lakukan.

\section{Simpulan}

Teologi transformatif adalah salah satu pembaharuan pemikiran keislaman yang dicetuskan oleh Moeslim Abdurrahman dengan menekankan pembelaan pada kaum dhu'afa dan mustadh'afin. Hal ini dipengaruhi oleh adanya kegelisahan Moeslim melihat realitas Indonesia dalam ekonomi dan pendidikannya terjajah oleh arus modernisasi yang menyebabkan berkembangnya marginalisasi di kalangan khalayak masyarakat. Teologi transformatif menekankan sebuah perubahan tatanan perekonomian dengan pengadaan pendampingan sosial dari sebuah organisasi yang mengumpulkan dana sebagai modal awal pembentukan usaha. Begitu juga dalam hal 
pendidikan, teologi transformatif mengharapkan adanya pembaharuan lembaga pendidikan berbasis pesantren sebagai lembaga yang tidak hanya mengkaji kitab kuning akan tetapi dijadikan sebagai pusat lahirnya para pemikir muslim yang mampu merekonstruksi tatanan kehidupan masyarakat menjadi lebih baik. 


\section{Referensi}

Abdurrahman, M. (1997). Islam Transformatif. Jakarta: Pustaka Firdaus.

Abdurrahman, M. (2003). Islam Sebagai Kritik Sosial. Jakarta: Erlangga.

Abdurrahman, M. (2005). Islam yang Memihak. Jakarta: LkiS.

Ahmad, K. (2011). Teologi Pembebasan dalam Islam: Telaah Pemikiran Asghar Ali Engineer, 10

Alfian. (1980). Kemiskinan Struktural: Suatu Bungan Rampai. Jakarta: Yayasan Ilmuilmu Sosial.

Baidhawy, Z. (2015). Kemiskinan dan Kritik atas Globalisme Neoliberal. Salatiga: LP2M Press IAIN Salatiga.

Fuad, A. N. (2015). Dari Reformis Hingga Transformatif: Dialektika Intelektual Keagamaan Muhammadiyah (Intrans Pu). Malang.

Ismail, F. (1993). Islam Pembangnan dan Modernisasi, TInjauan dari Sudut Transformasi Budaya. Yogyakarta: Pustaka Pelajar.

Kadar, M. . (2005). Pembelaan Al-Quran kepada Kaum Tertindas. Jakarta: AMZAH.

Khomsan, A., \& Dkk. (2015). Indikator Kemiskinan dan Misklasifikasi Orang Miskin. Jakarta: Yayasan Pustaka Obor.

Kuntowijoyo. (2008). Paradigma Islam: Interpretasi Untuk Aksi. Bandung: PT. Mizan Pustaka.

Madjid, N. (2000). Islam: Doktrin dan Peradaban. Jakarta: Paramadina.

Moh. Shofan. (2006). Jalan ketiga pemikiran Islam. Yogyakarta: IRCiSoD.

Muthoharoh. (2013). Teologi Islam Transformatif Menurut Moeslim Abdurrahman dan Relevansinya dengan Pemikiran Keagamaan di Era Kontemporer. IAIN Sunan Ampel.

Naim, N. (2016). Abdurrahman Wahid: Universalisme Islam dan Toleransi. Kalam, 10(Toleransi).

Rakhmat, J. (1994). Islam Aktual. Bandung: Mizan.

Rakhmat, J. (2004). Islam Alternatif. Bandung: Mizan.

Sabiq, S. (1982). Islamuna. Beirut: Dar Fikr.

Saputra, R. (2011). Teologi Transformatif(Studi Pemikiran Mansour Fakih). 
Universitas Islam Negeri Sunan Kalijaga Yogyakarta.

Shimogaki, K. (2007). Kiri Islam antara Modernisme dan Posmodernisme. Yogyakarta: LkiS.

Tasmuji. (2011). Teologi Transformatif Jaringan Islam Liberal. Teosofi: Jurnal Tasawuf dan Pemikiran Islam, 1(2).

Toha Rudin Rizal. (2016). Gambaran Konflik Bermatras Agama Di Indonesia (Problem Solving Berbasis Teologi Transformatif). El-Hekam, 1(1).

Wahyudi, A. (1999). Muhammadiyah Dalam Gonjang Ganjing Politik. Yogyakarta:

Media Presindo. 
Halaman ini bukan sengaja untuk dikosongkan. 